\title{
The Development Direction of Procuratorial Organs Under the Reform of State Supervision System
}

\author{
Sihan Liu \\ School of Art and Law \\ Wuhan University of Technology \\ Wuhan, China
}

\begin{abstract}
The thirteen session of the National People's Congress, held in March 11, 2018, adopted a new amendment to the constitution, marking the formal construction of the constitution as the core of the state supervision of the rule of law system. This involves not only the establishment and adjustment of state organs, but also the reconfiguration and structural changes of state power at the constitutional level.
\end{abstract}

Keywords-structural reform; procuratorial organ; procuratorial power

\section{INTRODUCTION}

Before the start of the national supervision system reform pilot work in 2016, the anti-corruption system in China is mainly the national public power supervision system, which is dominated by the discipline inspection and supervision, the procuratorial supervision as the guarantee and the administrative supervision as a supplement. The former state supervision system, which has been summed up by scholars as "three carriages" model, has played a certain historical role, but has exposed many problems in the reform of the current political system. The main problems faced by the procuratorial supervision system, which is the main force of our country's anti-corruption system, are as follows: the supervision of the procuratorial work is serious and the selfdetection and supervision has been reduced to selfsupervision, and the establishment and exercise of the authority of the procuratorial organs are focused and deviated, too much dependence on the litigation services such as investigation, arrest and prosecution, and the neglect of the litigation prison. The development of the function of the governor, especially the supervision of the civil administrative litigation and the criminal execution supervision, has been disbalanced. For a long time, the disputes on the basic theoretical issues such as the property of procuratorial power, the constitutional status of the procuratorial organs and the constitution of the procuratorial function have made the operation of the procuratorial system confined to the functional allocation of the experience. The constitutional orientation of the procuratorial organs and the structure of the actual functions have been misplaced, which deviate from the constitutional orientation of the "legal supervision organs", and the reform of the state supervision system has a great influence on the internal functions of the procuratorial organs. Therefore, under the circumstances of the reform of the judicial system and the state supervision system, from the level of the constitution, the influence of the personnel transfer and the adjustment of the power of the procuratorial organs on the reform of the procuratorial system will be helpful to straighten out the relationship between the internal functions of the procuratorial organs and provide an opportunity for the restructure of the inspection right in our country.

\section{THE DEBATE OF THE THEORY}

\section{A. Procuratorial Power Belongs to the Administrative Power}

The reason is that although the procuratorial organs do not belong to the administrative organs in the constitutional system of our country, it cannot be explained in theory by the actual legality, and the procuratorial power is only characteristic of partial judicature, and the essential attribute should be attributed to the state administrative power. First, from the principle of "procuratorial system", through the summary of the characteristics of the organizational system and the standard of action of the procuratorial organs, it can be concluded that the procuratorial power has the characteristics of the administrative power constructed at the next level and at the level of the hierarchy.The second is the structure and division of power in the constitutional system. According to Montesquieu's theory of the separation of three powers, the basic division of the structure of the western political power system is the separation and balance between the legislative power, the judicial power and the administrative power. In this structure, judicial power only refers to the judicial power of independence, neutrality and finality, and the procuratorial power does not belong to the independent power at the same level with the three powers. Third, by comparing the essential attributes and characteristics of judicial power and administrative power, we conclude that procuratorial power should be attributed to administrative power in essence.

The above analysis is mainly based on the functions of state organs and their systems, which distinguishes the functions of state functions, only in the form of differences. If the organization system and operating mechanism of the procuratorial organs have the characteristics of the administrative organs, the procuratorial power is defined as 
the administrative power, which is a very simple and onesided division. The administrative characteristics are only part of the procuratorial power, and cannot replace the overall attributes with local characteristics. Therefore, the property of procuratorial power should not be administrative power.

\section{B. Procuratorial Power Belongs to the Judicial Power}

From the constitution of China and the organization law of the people's Procuratorate, the expression of state institutions can be found that the procuratorial organs are not clearly defined as judicial organs, but are listed as "procuratorial organs" and "administrative organs", "supervisory organs" and "judicial organs". For a long time, our country has used the procuratorate and the court as the judicial organ, which is combined with the government as the law enforcement organ as the two level state organ, which is produced by the people's Congress as the legislative organ, and is responsible and supervised by the government. In addition, the party's documents often refer to the court and the procuratorate as the judicial organ [such as the decision of the Central Committee of the Communist Party of China on the comprehensive promotion of several major issues of the rule of law in the fourth Plenary Session of the 18th CPC Central Committee (hereinafter referred to as "the decision"): "to improve the judicial system and to promote the separation of the judicial power from the implementation of the system. "Reform of the reform of the judicial organs and property management system, to explore the implementation of the court, the procuratorate administrative power of judicial administration and judicial power and the separation of procuratorial power." The report of the Seventeenth National Congress of the party put forward: "deepen the reform of the judicial system, optimize the allocation of judicial power, standardize judicial acts, build a fair and efficient and authoritative socialist judicial system, and ensure that judicial organs and procuratorial organs exercise judicial and procuratorial power independently and impartially according to law.". Although the system is different from the three discrete modes of the western countries, the judicial organ which is only limited to the court has added the procuratorial organ, and the judicial power increases the procuratorial power. However, it should be recognized to consider the procuratorial system and the property of the procuratorial power of a country, not only to refer to the general norms of the procuratorial system abroad, but also to be based on this. The constitutional system and state power structure of the country start from its legislative system and judicial practice. This is the "two yuan judicial system" carried out under the political system of "one" in China. The procuratorial organs are considered to be the judicial organs parallel to the judicial organs, so the procuratorial power is of course judicial power.

In addition, according to the summary of the viewpoints of the scholars, we can draw a conclusion that the procuratorial power has the property of judicial power from the following aspects: first, our current law and judicial practice clearly stipulate that the procuratorial organ has the independent status with the court in the state system, the procuratorial organ exercises procuratorial power independently according to law, and is not subject to the administrative organs and the social groups. The interference of the body and the individual. The independence of the procuratorial organ is reflected in the relative independence of the prosecutor, which is mainly manifested in the principle of "procuratorial system" in the internal system of the procuratorial organs, but when the prosecutor applies the law to the specific case, it is independent judgment based on the case material he has mastered and the rational solution to the law. And the prosecutor's right of instruction is limited. Prosecutors can freely express themselves in court without restriction. This is consistent with the independent handling system of prosecutors since the fourth Plenary Session of the 18th CPC Central Committee.

Although the reform of the procuratorial system tends to be judicatory, for example, under the reform of the state supervision system, the procuratorial function system of "investigating as the center" is fundamentally changed, and the duty investigation right of the procuratorial organ is transferred to the state supervisory committee, so that the judicial attribute of the procuratorial organ is clearer. . In combination with the reform of the judicial system, the procuratorial organs will revolve around the procuratorial reform that conforms to its own positioning and development, and reconstructs the functional system centered on the right of public prosecution, which is based on the reform of the litigation system centered on the right of trial. However, it is also necessary to realize that the simple determination of procuratorial power as judicial power and the positioning of the procuratorial organs as judicial organs cannot completely explain the other part of the administrative power of the procuratorial power. Some scholars have already criticized this. Some scholars believe that the two different powers, which are exercised by the court and the procuratorate, are mixed together as judicial power or judicial organ, which are contrary to the rules of the state power structure of the rule of law; some scholars believe that although no one denies the prosecutor "close to" the judge, it is close to it after all. Don't be equal. The judge's trial system has no internal justices, judges have independent judgment and identity protection, and prosecutors are not fully entitled to it. Some scholars believe that the procuratorial power is only a part of the judicial power, and the characteristic is only relative and incomplete. In addition, the independence of the prosecutor is only relative, and it cannot change the nature of the procuratorial power.

Therefore, locating the judicial power in the nature of procuratorial power has also fallen into the dilemma of unilaterally replacing the whole.

\section{Procuratorial Power Belongs to the Right of Legal Supervision}

From the relevant provisions of the constitution of our country and the organization law of the people's Procuratorate and the mainstream view in the procuratorial system, the property of procuratorial power should be the right of legal supervision, because the procuratorial organ is defined as the legal supervision organ at the level of 
constitutional norms. However, through the analysis of the judicial power of the procuratorial power, it can be seen that in the actual level, the current legal system and the state power structure system, the procuratorial organs are also the judicial organs, and perform the judicial power. The contradiction in this real law needs to be solved from the theoretical understanding.

The three power separation mode of western countries regards the procuratorial organs as the spokesmen for the interests of the government or the public interests, especially in the Anglo American law countries, which stipulates the procuratorial organ as equal to the lawyer, and has the same burden of proof and duty as the prosecution and the lawyer in the court. As a socialist country, the procuratorial system of the people is established on the basis of the 1936 constitution of the Soviet Union. The Constitution stipulates the power of the procuratorial organs to supervise the organization of all organs, the human rights of the public office of the state, and the exact compliance of the citizens with the law. This shows that the constitution of the Soviet Union stipulates the procuratorial machine. General supervision is exercised by customs. This is Lenin's thought of legal supervision. In this way, the procuratorial organ is established as a legal supervision organ. Through the analysis of a series of functions and powers of the procuratorial organs since the founding of the people's Republic of China, it can be roughly analyzed that the legal supervisory power of the procuratorial organs has gone through the process of changing the right of legal supervision from the general supervision to the narrow sense, which has a great influence on the understanding of the power property of the procuratorial power.

However, the establishment of the general supervision right is due to the temporary and special nature of the transitional state to consolidate the national institutional system, maintain the national unity of legal system and ensure the effective implementation of the state law by giving special rights to the procuratorial organs in the transitional period. From the constitutional system and the state power structure of our country, the general supervision of the administrative organs and the judicial organs by the procuratorial organs is undoubtedly the act of crossing the power, which destroys the two level state power system of our country under the leadership of the people's Congress, and the excessive and extensive supervision of the procuratorial organs will also cause the internal administration. Interference in power operation and influence on independent adjudication of judicial organs. Therefore, in 1979, the procuratorate organization law and the 1982 Constitution stipulate the people's Procuratorate as "the legal supervision organ of the state", and the provisions of the general supervision right have been cancelled, and the powers of the procuratorial organs have been adjusted. However, it should be noted that the procuratorial organs still retain the supervision of the court's trial activities, public security organs' investigation activities, and the execution of criminal cases. Although the current judicial system reform requires the establishment of a "trial centered" reform of the litigation system, the procuratorate has constantly weakened the direct supervision of the court's trial activities and avoided the prosecutor from becoming a "judge above the judge", but it is fundamentally determined by the constitutional orientation of the "legal supervision organ" of the procuratorial organ. The basic principle of its allocation of power and the operation of power. Compared to Russia, which also places the procuratorial organ as the legal supervision organ, it can be found that Russia has abolished the judicial supervision of the activities of the court, which is the main difference between China and the Russian procuratorial organs.

At present, the legal supervision authority of the procuratorial organs is fixed in the scope of litigation, especially in the field of criminal procedure, which seems not to be in accordance with the regulations on the status of the constitution. From the constitutional level, the right of legal supervision should be macro power, and it can supervise all aspects other than legislation in the mechanism of law operation, and the object of supervision is the use of state power. However, from the actual function of the procuratorial organs, as well as the implementation of the reform of the procuratorial system in recent years, the procuratorial organs mainly take litigation activities, the judicial trend of procuratorial power is obvious, and the procuratorial litigation system has developed more and more to the "litigant" criminal litigation structure of the Anglo American law system. Therefore, the academia described this phenomenon as "the dislocation of the procuratorial organ's constitution in the functional orientation". The emergence of this problem is not only due to the lack of systematic and in-depth theoretical research on the procuratorial system and legal supervision of the transplanting from foreign laws. Only on the basis of practice and experience, it does not reflect the arrangement of the actual power from the constitutional orientation of the legal supervision organs, and does not form the principle of logic and power allocation in the organization of the regime. From a holistic perspective, we can understand the structural function of procuratorial organs and their powers in the constitutional system.

The above debate has always affected the reform and construction of the procuratorial system, so when the state supervision system reform divides the investigative power of the duty crime from the procuratorate and transfers part of the functional departments of the procuratorial organs, there are many views that it will deprive the procuratorial organs to carry out the important means and ways of supervising the procuratorial organs, and even shake the procuratorial machines. Guan's constitutional position and the legal supervision power of procuratorial power. The procuratorial system of our country has undergone several great changes since the founding of the People's Republic of China. The functions and powers of the procuratorial organs are adjusted according to the changes in the organization and the situation of the state power. It is a normal change and is in line with the needs of the reform and development of our country. Under the opportunity of judicial reform and state supervision system reform, the existing legal supervision right theory and the procuratorial function allocation system 
can be rethought. From the state public power structure and the constitution system, the position of the procuratorial organs' legal supervision organs and the quality of the procuratorial power as the legal supervision power are reexamined. Clarifying the power and value of procuratorial power and the functional structure of procuratorial organs after reform is an opportunity to further promote the reform of procuratorial system.

\section{RESHAPING THE SYSTEM CENTERED}

The influence of the reform of the state supervision system on the procuratorial system is in essence a reexamination of the property of the procuratorial power and the constitutional orientation of the procuratorial organs; in form, it represents the reorganization of the functional institutions of the procuratorial organs and the transfer of the center of gravity of the business, for example, the investigation of corruption and bribery, dereliction of duty and prevention of the procuratorial organs. The related functions of the duty crime department are integrated into the State Supervision Committee, which makes the procuratorial organs lose the power of investigation and procuratorial supervision, and faces the difficulties of reconstructing the functions and powers, reorganizing the departments, and transferring the personnel to the subordinate, thus promoting the adjustment and perfection of the internal system of the procuratorial organs in coordination with the reform.

The function of public prosecution is the basic function and duty of procuratorial organ, and it is in the central position in the whole procuratorial organ's function system. No matter how the reform is carried out, the public prosecution system will not be changed. The adjustment and modification is only the other functions undertaken by the procuratorial organ. The procuratorial function system, which is based on the general supervision right based on the constitution of 1954, or the procuratorial function system, which was established as the center of investigation, is the wrong understanding of the property of procuratorial power and the misunderstanding of the allocation of procuratorial organ's power. For example, before the reform, the procuratorial organ regarded the right of investigating the duty crime as the focus of business, which made the investigation and trial supervision become a strong business, and even established a "Investigation Centered" functional system, which seriously affected the objectivity and impartiality of the procuratorial power. On the other hand, the power of the procuratorial organs to put forward the protest and procuratorial opinion on the wrong referees and the legal proceedings should belong to the right of public prosecution, but in the past, the procuratorial organs have been wrongly defined as the jurisdiction of the trial and made the procuratorial organs fall into the paradox.

It should be realized that both the protest and the procuratorial opinion are the objections of the prosecutor to the judge's illegal or improper action. It is to express his own opinions and ask the judge to make the right treatment. Therefore, this is the right of litigation in the trial process and should belong to the right of public prosecution. Therefore, the criminal prosecution should respond to the reform of the litigation system centered on trial, and establish the evidence centered criminal prosecution system around the substantive trial.

In addition, a misunderstanding of public prosecution right in practice for a long time is to understand the public prosecution in a narrow sense as a criminal prosecution, ignoring the development of civil public prosecution and administrative public prosecution. Although the harm caused by criminal activities to the society has the characteristics of serious consequences and extensive influence, the current criminal procedure legislation only stipulates how to exercise the right of public prosecution by the procuratorial organs. However, the procuratorial organ is the representative of the public interest, and the essential feature of the right of public prosecution is that the procuratorial organ prosecute the acts against the public interests on behalf of the state or society, and the infringement is not only limited to the criminal act, but all the actions that harm the public interests are all attributable to the scope of the prosecution. Therefore, the procuratorial organ's right to public prosecution can be divided into the right of public prosecution, the right of civil prosecution and the right of public prosecution.

This is not only to fill and reconfigure the functions and powers of the procuratorial organs, but also to reexplore and plan the reform of the procuratorial system.

First of all, from the administrative public interest litigation. In the past, the procuratorial organs' supervision of the administrative organs mainly relied on the prosecution of criminal acts such as corruption and malfeasance of administrative personnel, and the scope of the cases was limited to the field of criminal offences. There is no comprehensive and systematic supervision on the administrative law enforcement inaction and law enforcement illegal activities in the general field, and it is only summed up in the internal supervision system of the administrative organs which are the main body of administrative reconsideration and administrative litigation, and there is no effective supervision over the loss of the state and public interests caused by administrative illegality and administrative inaction. . At present, the procuratorial organ may violates the authority or inaction of the administrative organs of supervision and administration rich in the fields of ecological environment and resources protection, food and drug safety, state property protection, the transfer of the right to use state land and other fields, causing the interests of the state or the social public to be infringed on, and to the administrative machine. Customs proposes procuratorial suggestions or raises administrative public interest litigation.

Secondly, from the civil public interest litigation. Civil public interest litigation involves most social public interests, such as the destruction of the ecological environment and the protection of resources, the infringement of the legal rights and interests of many consumers and the damage to the public interests in the field of food and drug safety. The object of the infringement is the unspecific consumers or enterprise units in the society. In view of such violations, the law stipulates that organs and social organizations can bring civil public interest litigation on behalf of them. At this time, 
procuratorial organs cannot involve themselves. But when there is no statutory or appropriate organization or social organization, the procuratorial organ can bring civil public interest litigation as the final relief for such cases. It can be said that public interest litigation, as a new function of the procuratorial organ, has perfected the contents of the public prosecution system of the procuratorial organs, made up for the past procuratorial organs to supervise the related fields, and also developed the civil litigation and administrative litigation functions within the procuratorial organs, and is beneficial to the procuratorial functions of the procuratorial organs with public prosecution as the center.

\section{THE FORMATION OF A SYSTEM}

\section{A. Differences}

The reform of the state supervision system has integrated the departments of supervision of the previous administrative organs, the national Corruption Prevention Bureau, the judicial organs to investigate and deal with corruption, misconduct and dereliction of duty and the prevention of duty crimes into the State Supervision Committee, work together with the discipline inspection department, supervise all public officials exercising public power, and unify the exercise of anti-corruption. Lose power. Although the State Supervision Committee has integrated some of the functions originally belonging to the procuratorial organ, it has not deprived the procuratorial organs of legal supervision, and the supervisory authority of the procuratorial organs and the supervisory authority of the state supervision committee still have obvious differences.

First, from the object of power point of view, the supervisory committee of the supervisory committee is limited to the corruption and corruption of public officials exercising state power, and does not involve the operation and decision of the power of other state institutions; however, the object of supervision of the procuratorial organs is the conduct of the state organs, that is, whether the administrative organs exist or not. Or illegal acts, whether there are wrong referees or illegal referees. It can be summed up as "human rights" and "right of administration".

Secondly, from the scope of the power contained, the supervisory committee's supervisory scope includes the compliance of the public officials in accordance with the law, the impartial right to use, and the integrity from the government to the moral integrity, that is to say, the supervision committee has been monitored from the duty crime to the general violation of discipline and moral norms; The scope of supervision of the procuratorial organs is limited to whether the activities of state organs are legitimate. It is based on law rather than Party discipline, Party discipline and moral norms.

Third, from the way of exercising power, the three main functions and powers of the supervisory committee are supervision, investigation and disposal, which can be disposed of by the general supervision committee of public officials who are generally illegal and unlawful, but for public officials suspected of being suspected of duty offense, the authority of the supervisory committee only has the right to dispose of it. Procedural, not the final right to decide, it is still necessary for the procuratorial organ to decide whether to prosecute and to make the final judgment by the court; however, most of the ways of exercising the legal supervision right of the procuratorial organs are procedural, that is, to judge the cases by the prosecution or the initiation of the retrial procedure by the protest, in addition to this accident. Notification of correction of illegal activities and procuratorial advice is also the exercise of procedural power.

\section{B. Complementary Relationship}

The relationship between the State Supervision Committee and the procuratorial organ is not the relationship of this generation of conflict, but the relationship of mutual supplement and mutual remedy, thus forming a comprehensive and systematic state power restriction system under the reconstruction of constitutional power structure.

First, effective linkage mechanism between procuratorial system and state supervision system is constructed. The procuratorial organs and the State Supervision Committee cooperate with each other and coordinate the division of labor, so that the procuratorial organs have an effective supervision system for the supervision of behavior and the supervision by the supervisory organs to the supervision of the personnel. And when involved in the criminal activities of public officials, it is clear whether the evidence material obtained by the supervisory committee can be directly used by the procuratorial organ, and the case should be transferred to the procuratorial organ when the prosecution is prosecuted. In addition, in the legal supervision of the legal nature of the state organs, the procuratorial organs should find out how to apply for the supervision committee to intervene in the case investigation if there are problems such as illegal violation, corruption, misconduct and dereliction of duty.

Secondly, the effective supervision and restriction mechanism of the procuratorial organs to the state supervisory committee is established. As an unprecedented huge anti-corruption agency, the power of the State Supervision Commission will not be effectively restricted and supervised, which will cause the dissimilation of power and even destroy the original purpose of the establishment of the system. As the guardian of the law and the representative of the public interests of the state and society, the procuratorial organs can supervise and restrict the illegal acts of the supervisory committee in the process of exercising power. For example, the procuratorial organs can exercise legal supervision by examining whether the crime cases transferred by the supervisory committee comply with the conditions of the prosecution, and the procuratorial organs can also supervise the legal supervision of the civil rights of citizens and the property rights of citizens, legal persons and other organizations by the supervision committee to achieve the purpose of safeguarding human rights.

\section{CONCLUSION}

The reform of the state supervision system has changed the power structure of our country, also changed the power 
and authority configuration of the procuratorial organ, which has greatly influenced the current procuratorial system. Through the opportunity of reform, reviewing the property of procuratorial power and defining the constitutional orientation of procuratorial organs in the new constitution system, it is beneficial to push forward the deepening of the procuratorial reform and reshape the procuratorial system with public prosecution as the center, and try to build an effective linkage between the procuratorial system and the state supervision system. Thus, a comprehensive and systematic system of public power restriction is formed.

\section{REFERENCES}

[1] Wang Yiming,"The introspection and Prospect of the evolution of the function orientation of the procuratorial organs,"J.Journal of Lanzhou University(SOCIAL SCIENCE EDITION).Feb.2017,pp.92-94.

[2] Hu Yong,"Re positioning and functional adjustment of procuratorial organs under the reform of supervision system,"J.Study on the Rule of Law.Feb.2017,97-105.

[3] Han Dayuan,"On some constitutional problems in the reform of state supervision system,"J.Legal review.Mar.2017,110-117.

[4] Wang Xuanwei."'The reform of the state supervision system and the development of the procuratorial organs,"J.The Rule of Law of the People.May.2017,97-103.

[5] Chen Ruihua,"On the Legal Function of the Procuratorial Organs ,"J. Political and Law Forum.Jan.2018,91-97. 